\title{
Article
}

\section{Five Million Poems, or the Local Press as Poetry Publisher, 1800-1900}

Hobbs, Andrew

Available at http://clok.uclan.ac.uk/11418/

Hobbs, Andrew ORCID: 0000-0001-5943-475X (2012) Five Million Poems, or the Local Press as Poetry Publisher, 1800-1900. Victorian Periodicals Review, 45 (4). pp. 488-492. ISSN 1712-526X

It is advisable to refer to the publisher's version if you intend to cite from the work. http://dx.doi.org/10.1353/vpr.2012.0044

For more information about UCLan's research in this area go to

http://www.uclan.ac.uk/researchgroups/ and search for <name of research Group>.

For information about Research generally at UCLan please go to http://www.uclan.ac.uk/research/

All outputs in CLoK are protected by Intellectual Property Rights law, including Copyright law. Copyright, IPR and Moral Rights for the works on this site are retained by the individual authors and/or other copyright owners. Terms and conditions for use of this material are defined in the policies page.

\section{CLoK}

Central Lancashire online Knowledge www.clok.uclan.ac.uk

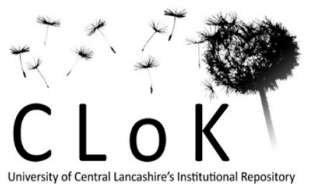




\section{PROJECT MUSE*}

Five Million Poems, or the Local Press as Poetry Publisher, 1800-1900

Andrew Hobbs

Victorian Periodicals Review, Volume 45, Number 4, Winter 2012, pp.

488-492 (Article)

Published by The Johns Hopkins University Press

DOI: 10.1353/vpr.2012.0044

$\Rightarrow$ For additional information about this article

http://muse.jhu.edu/journals/vpr/summary/v045/45.4.hobbs.html 


\title{
Five Million Poems, or the Local Press as Poetry Publisher, I 800-I900
}

\author{
ANDREW HOBBS
}

Poetry is now accepted as a ubiquitous part of the Victorian periodical thanks to the work of Linda K. Hughes, Kathryn Ledbetter, Natalie Houston, and Alison Chapman. ${ }^{\mathrm{I}}$ My small research project, The Local Press as Poetry Publisher, I800-I900, aims to join the debate by saying, as I often do, "Don't forget about newspapers, especially the local paper." Throughout the Victorian era, local newspapers were widely read publications, reaching a broader readership than London newspapers, magazines, and reviews, let alone part-works or books. Most issues of local newspapers regularly published one or two short poems, which were often located in sections specifically dedicated to poetry. It seems high time, therefore, to examine the local newspaper as a poetry publishing platform. My aim is to foreground the nineteenth-century local newspaper as a venue for poetry by estimating the number of poems published in local newspapers and by exploring case studies of particular newspaper titles and poets as well as local literary cultures and their links to national networks.

The British Library's digitization of more than one hundred nineteenthcentury local newspapers made such a project manageable. I was especially grateful for the help of a paid graduate intern, Claire Januszewski, who spent the summer finding, reading, and classifying more than I, 800 poems. Claire consulted I,066 individual newspaper issues, finding an average of two poems per week in the five weeklies sampled, five poems per week in one morning paper sampled, and one poem every nine days in the evening paper sampled. About 70 percent of issues contained at least one poem, sometimes as many as ten.

Extrapolating from this research, I estimate that there were five million individual poems published in the English provincial press during the nineteenth century, give or take a million. This is how I did the sums. In I $80 \mathrm{I}$, there were ninety-nine provincial weekly papers publishing an aver- 
age of two poems per week, multiplied by fifty-two weeks per year, making a total of about ten thousand poems published in that year's provincial press alone. I added the estimated total for each year of the century, using the same total of newspaper titles as a multiplier for the following twenty years. (This greatly underestimates the total of newspapers for nineteen out of every twenty years, which was of course constantly increasing.) Similar calculations were made for daily papers in later sample years. A surprisingly small percentage of poems appeared in more than one paper. To make my research project manageable, I chose five titles:

- The Blackburn Standard, a small-town Lancashire Tory weekly;

- The Manchester Times, a big-city Radical weekly that became a magazine-style weekly miscellany of Liberal and then Tory politics;

- The Hampshire Telegraph, a Radical then Liberal weekly covering an entire county from Portsmouth;

- The Bristol Mercury, another big-city Radical weekly that produced a Liberal morning offshoot;

- The Middlesbrough Evening Gazette, an advanced Liberal evening paper.

I realise that social science terms like "sampling" are an anathema to literary scholars, so it may be best to refer to them as case studies. The biggest weakness of the case study titles is their bias to Liberal/Radical politics, which seems to affect the political flavour of the verse but not the quantity.

Claire looked at every issue of the weekly papers and one in eight issues of the dailies (ensuring coverage of every publication day across the week) in the years I $800, \mathrm{I} 820, \mathrm{I} 840, \mathrm{I} 860, \mathrm{I} 880$, and I900. The poetry published in newspapers was a mixture of reprinted and original verse. The reprinted poetry includes canonical writers such as Tennyson, Shakespeare, and Keats, as well other writers who were hugely popular at the time, including Felicia Hemans, Georgiana Bennett, and radical poets like John Critchley Prince. The poems of more obscure writers, whose work often commented on contemporary events, were lifted from other newspapers and periodicals. Many American poems appeared towards the end of the century.

We know less about the original poetry, for obvious reasons. I hope to research a small sample of poets and recreate the local contexts within which poetry was submitted, selected, edited, mediated, and published by local newspapers. Obituaries and autobiographies (such as those in the Archive of Working-Class Writing based at Liverpool John Moores University) are useful resources for conducting this research. ${ }^{2}$ We are also looking for evidence of people actually reading these poems-for example, through readers' letters, reply poems, commonplace books, and scrapbooks. Claire 
and I have recorded the details of each poem ${ }^{3}$ on an Excel spreadsheet, which is available on a research blog that I am using to record the progress of the project: http://hobbb.tumblr.com.

As one might expect, this exercise has already suggested many topics to pursue. I hope to ascertain which "known" poets and poems were most popular, to gather biographical information about poets with a strictly local reputation, and to investigate the local literary cultures of which the newspapers were part. I am also interested in how local and national literary networks were connected. For example, by chance we chose the Blackburn Standard, a newspaper which was produced with central Tory party funding, one of more than twenty around the country edited in London by Alaric Watts, a journalist and poet best known for his poetry annual the Literary Souvenir.

The digitization of newspapers enables word-searching to find information on poets, editors, and the circumstances in which poetry was published and received. And, as with conventional newspaper research, whilst searching for something else I accidentally gathered much useful information: obituaries of poets, poetic tricks played on editors, arguments between poets and readers over the importance of poetry, and poems written about editorial rejection and criticism (some cruel, some kind).

If I can convince a few scholars of the significance of the local press as a publishing platform for "literary" material, I hope those with more literary expertise than I will do more with this material in the future. The topic of working-class poets has been well covered elsewhere, particularly by Brian Maidment, and my initial research on Blackburn poets confirms his insightful analysis of these writers as bards, or "slightly more articulate neighbour[s]." ${ }^{4}$ However, there is still plenty of room for research in this and other areas.

Other assorted findings I may or may not pursue include the high proportion of poetry from the United States and the large number of poems about the second Boer War. It may also be interesting to investigate the way in which the local press republished content from metropolitan publications such as Punch and other weekly and monthly magazines, increasing their influence enormously. I am keenly interested in print culture and local identities, including dialect poetry, so it has been gratifying to see the local flavour of many poems, even those selected from London publications.

What has struck me the most is evidence that poetry was not seen as an exclusively literary genre; it was also a journalistic genre used widely to comment on the news. Even more broadly, it was a newspaper genre, appearing in advertisements for clothes, beer, and sausages. In fact, judging by the quality of some of the poems accepted and the editorial comments about the submissions that were rejected, poetry seems to have been viewed as a method of communication or a way of thinking that was open 
even to those with little or no poetic ability. It was imagined as just another style of talking or writing.

I am conducting research on this project in a public forum via my research blog in the hope of reaching beyond academia as an experiment in "crowd scholarship." The digitized newspapers I am using are widely available in British universities and public libraries as well as through university libraries in other parts of the world. I am eager to benefit from the expertise of those who know far more about nineteenth-century newspapers and poetry than I do. I am hoping members of RSVP might be willing to look at my bibliographical spreadsheet ${ }^{5}$ and help in one of the following ways:

- Identify poetic forms and genres.

- Add a comment that we can incorporate into the spreadsheet.

- Identify poets' names or the originals of parodies.

- Identify the authors of anonymous or unattributed poems.

- Spot any patterns, absences, trends, or anomalies.

By asking for your help, I am hoping to take advantage of the possibilities of digital and online collaboration. (Or it may just be a cheeky request for help with my research project!) In return, I will make the raw "data" and scraps of information I have gathered available to all. The experience of writing a research blog has been useful, providing an incentive to complete each step of research, but the pace has slowed now that my teaching responsibilities have resumed.

I am hoping The Local Press as Poetry Publisher, I800-1900 in a small way complements the two existing useful online databases of Victorian periodical poetry: the Database of Victorian Periodical Poetry and the Periodical Poetry Index. My contribution to this field is part of a wider putative project which aims to examine the huge quantity of writing in the local press that was not written by full-time reporters or editors but by a secret army of Victorian citizen-journalists who connected newspapers to their communities.

University of Central Lancashire

\section{NOTES}

I. Linda K. Hughes, "What the Wellesley Index Left Out: Why Poetry Matters to Periodical Studies," Victorian Periodicals Review 40, no. 2 (2007): 9I-I 25; Kathryn Ledbetter, Tennyson and Victorian Periodicals: Commodities in Context (Farnham: Ashgate, 2007); Natalie Houston, "Newspaper Poems," Victorian Studies 50, no. 2 (2008): 233-42; Alison Chapman, 
Victorian Poetry Network, last modified October I2, 201 2, http://web.uvic. ca/ vicpoet/.

2. Archive of Working-Class Writing, Liverpool John Moores University, last modified March 29, 20I 2, http://www.ljmu.ac.uk/HSS/I 22820.htm.

3. For each poem, Claire has recorded the title; first line; newspaper; date; page number; number of lines; author, if known; poetic genre and topic; and source, if acknowledged.

4. Brian Maidment, "Class and Cultural Production in the Industrial City: Poetry in Victorian Manchester," in City, Class and Culture: Studies of Cultural Production and Social Policy in Victorian Manchester, ed. A. J. Kidd and K. Roberts (Manchester: Manchester University Press, I985), I 59.

5. "Bibliographic Listing of Poems in $19^{\text {th }}$ Century Local Newspapers," The Local Press as Poetry Publisher, I800-I900, last modified July 9, 20I 2, http://hobbb.tumblr.com/post/26860269393/bibliographical-listing-ofpoems-in-I9th-century-local. 